\title{
Capitalism and the Construction of Old Age
}


Critical Texts in Social Work and the Welfare State

General Editor: Peter Leonard

\author{
Published \\ Pete Alcock and Phil Harris \\ WELFARE LAW AND ORDER
}

Steve Bolger, Paul Corrigan, Jan Docking and Nick Frost TOWARDS SOCIALIST WELFARE WORK:

WORKING IN THE STATE

Paul Corrigan and Peter Leonard

SOCIAL WORK PRACTICE UNDER CAPITALISM:

A MARXIST APPROACH

Norman Ginsburg

CLASS, CAPITAL AND SOCIAL POLICY

Ian Gough

THE POLITICAL ECONOMY OF THE WELFARE STATE

Chris Phillipson

CAPITALISM AND THE CONSTRUCTION OF OLD AGE

Forthcoming

Christopher Jones

SOCIAL WORK PROFESSIONALISATION

Geoffrey Pearson

IDEOLOGICAL CRISIS IN SOCIAL WORK 


\title{
Capitalism and the Construction of Old Age
}

\author{
Chris Phillipson
}


(C) Chris Phillipson 1982

All rights reserved. No part of this publication may be reproduced or transmitted, in any form, or by any means, without permission.

First published 1982 by

THE MACMILLAN PRESS LTD

London and Basingstoke

Companies and representatives

throughout the world

ISBN 978-0-333-28644-9 ISBN 978-1-349-16929-0 (eBook)

DOI 10.1007/978-1-349-16929-0

Typeset in Great Britain by

STYLESET LIMITED

Salisbury, Wiltshire

The paperback edition of this book is sold subject to the condition that it shall not, by way of trade or otherwise, be lent, resold, hired out, or otherwise circulated without the publisher's prior consent in any form of binding or cover other than that in which it is published and without a similar condition including this condition being imposed on the subsequent purchaser. 
To Jane 


\section{Acknowledgement}

The author and publishers are grateful to the Editor of The Lancet for granting permission to quote from an editorial published 3 November 1973. 


\section{Contents}

Acknowledgements $\quad$ x

Editor's Introduction

1 Introduction: Capitalism and the Elderly 1

Radical perspectives on old age 5

The plan of the book 6

2 The Social Context of Ageing and Retirement 7

The demographic context $\quad 8$

The financial context 9

The health context 11

The politics of occupational pensions 13

3 The Emergence of Retirement 16

$\begin{array}{ll}\text { Introduction } & 16\end{array}$

The emergence of retirement: the historical back$\begin{array}{ll}\text { ground } & 17\end{array}$

Old age and retirement: the interwar period 18

Retirement and the labour movement $\quad 22$

The emergence of retirement: the postwar experience 28

Retirement in the 1980s and 1990s 35

Concluding comments $\quad 37$

4 Men in Retirement and Old Age 39

Introduction $\quad 39$

The entry into retirement $\quad 40$

The experience of retirement 42

Class and social activities in retirement 47

Liberation in retirement $\quad 49$

The late stages of retirement $\quad 51$

Capitalism and retirement $\quad 54$ 
5 Women in Retirement and Old Age 61

The position of older women in women's studies $\quad 62$

Women as workers $\quad 64$

Female labour under capitalism: some implications for later life

Women in old age

A profile of the older woman $\quad 72$

Continuities in later life $\quad 74$

Concluding comments $\quad 75$

6 State Legislation and the Elderly $\quad 77$

Introduction $\quad 77$

Social welfare and the elderly $\quad 78$

Social reform and the elderly $\quad 81$

The National Health Service $\quad 86$

The economic circumstances of pensioners $\quad 89$

Public expenditure cuts and the elderly 96

Concluding comments: old age and social policy $\quad 99$

7 Care and Control of the Elderly 103

Social work responses to the elderly 103

Social work practice: history, ideology and political organisation

Social work perspectives and the elderly 108

Working-class experiences of old age 111

Doctors and the elderly 115

The elderly and the social organisation of medicine $\quad 119$

8 Political Struggle and Organisation $\quad 122$

$\begin{array}{ll}\text { Introduction } & 122\end{array}$

The political sociology of ageing $\quad 124$

Old age: a radical future? 125

Political organisation among the elderly 131

American old-age movements: the postwar experience 133

The politics of ageing: the British experience 136

Political and community work with pensioners: some examples

Concluding comments 
9 Capitalism, Socialism and the Construction of Old Age 152 Capitalism in crisis

Retirement and the development of capitalism

Retirement: the attitudes of the state and the community

Socialist construction and old age

Socialist societies and old age

A socialist social policy for the elderly: some key questions

Summary

Endnotes

References

Index 


\section{Acknowledgements}

There are a number of individuals and organisations who have given support and encouragement to the completion of this book. First and foremost, Jane Taylor has been of enormous help in improving the quality of the text and providing criticism of early drafts. She has shared the experience of writing this study, becoming closely involved in many of the ideas and arguments which are developed. I owe her a considerable debt.

A number of people have offered friendship and advice during various stages of the book's completion. I would like to make particular mention of Mike and Jill Holbrook, Brian Williams, Chris Jones, Tony Novack, Aleda Erskine, and Gavin and Gill Williams. Dave Cox and Peter Tetley at Birmingham Polytechnic and Philip Abrams, Huw Beynon and Bob Roshier at Durham University have also offered me valuable help. Bob Roshier was my Ph.D. supervisor and I owe him a special debt of gratitude for his support and advice. Many of the ideas developed for my Ph.D. thesis are contained in this book and I am grateful to the SSRC for their financial support during my period of full-time study.

The inter-library loans desks at Durham and Keele, and the librarian at the Centre for Policy on Ageing, have offered valuable help and advice. Peter Leonard, and Steven Kennedy of Macmillan, have given skilled guidance at all stages of the book's development. Finally, Marion Rhodes typed my manuscript with great skill and patience and she responded quickly and with great forebearance to numerous deadlines.

University of Keele

December 1981

CHRIS PHILLIPSON 


\section{Editor's Introduction}

The fact that in capitalist society people are valued primarily in economic terms is nowhere more clearly demonstrated than by an examination of social policy towards the elderly. In recent years the term 'ageism' has been invented to identify a wide range of social practices which discriminate against people on account of their old age, from institutional policies and activities which abuse and harm the elderly to typically 'ageist' remarks which dismiss, belittle and insult them. The study of ageism as a social phenomenon in a wide range of societies is an important development which deserves widespread support on the Left. It is necessary, however, for such studies to be firmly located structurally so that individual practices and experiences can be understood in relation to wider economic and ideological forces. In Capitalism and the Construction of Old Age Chris Phillipson undertakes this precise task and so makes an important contribution to the study of ageism in the welfare state as well as extend, in very significant ways, the general Marxist analysis of social policy to which this series of Critical Texts in Social Work and the Welfare State is committed.

Although we can identify elements of oppression and discrimination against the elderly in many contemporary and past societies, when we consider our own society we must first be able to identify precisely the social relations and the accompanying ideologies which support and legitimate such oppression and discrimination. So far as social policy in relation to the elderly is concerned, we can see at once that what is significant is that people generally are evaluated in relation to their accumulation of capital, their current labour power (if the market requires it) or their ability to reproduce labour 
power, and that therefore those without wealth who are outside both production and reproduction (the elderly and the severely handicapped) are most likely to fare badly so far far as welfare provision is concerned. Thus the treatment of the elderly is mediated by the facts of class and gender; in particular, wealthy, ruling-class elderly are highly favoured and often retain substantial power over other people's lives as well as their own, in marked contrast to the working-class elderly, especially women.

But being dismissed as of no account or being actively discriminated against is not an experience of the workingclass elderly for which the Right is solely to blame. On the Left, too, patronising and dismissive attitudes and practices have been quite evident. It would be comforting to excuse such aberrations as simply reflecting elements of dominant ideology from which socialists have not yet struggled free; it must be admitted, however, that both the economism of earlier Marxist theory and practice and the emphasis on social reproduction which is more characteristic of presentday socialist feminism have at times the effect of marginalising the elderly. Emphasis on the revolutionary potential of, first, producers (male industrial proletarians), and then reproducers (women engaged in the task of family socialisation) has inevitably reinforced the position of the elderly as largely redundant as agents of radical change.

So far as the state is concerned, ideological justification for the discrimination and neglect of the working-class elderly is a tricky matter. The stigma which attaches to the elderly poor is not as public as that which, for example, attaches to black youths or single-parent mothers, and so it cannot be used so easily to fragment the working class and thus obtain support for policies directed against the elderly. The elderly poor are 'deserving' so they can be patronised, neglected, but not openly attacked. But there is a range of justifications available to support our responses to old age and these deserve very close examination. Perhaps the most important of these ideological supports is biological reductionism, whereby the real physiological and biological changes which take place with ageing are often utilised as a justification for denying old people the right to participate in decisions which affect 
them and generally to control their own lives. To emphasise, as Chris Phillipson does, the social construction of ageing is not to deny the facts of physical ageing, but to point to the difficulty of deciding precisely where the boundary lies and to note the way in which the latter is used to justify the former. Psychological explanations, of every level of sophistication and simplicity, are similarly available to account for the way the elderly poor are treated. Thus the necessary material and physical dependency of many elderly people is interpreted as 'child-like' and used to justify treating them as if they were children. Furthermore, infantilising the elderly eventually produces its own predicted result - old people may be induced to accept a 'child-like' role as the only legitimate way in our society of being physically dependent upon another person.

Certain social justifications are also available to support, in effect, policies of neglect and discrimination directed to the elderly. It is suggested, for example, that old people want to disconnect themselves from the world, to retreat from life in preparation for death. In so far as some old people wish to 'disengage' (and there is much dispute about this) we must ask ourselves to what extent this is a socially constructed disengagement from a set of social relations experienced predominantly as stigmatising and neglectful. Certainly, we must be aware of the extent to which 'disengagement theory' and other explanations of the social phenomenon of ageing are used to suggest that the elderly have only limited, simple and even subsistence needs (especially if they are very elderly working-class women) and that therefore only minimum welfare provision is necessary.

Capitalism and the Construction of Old Age shows us how minimum much of this welfare provision is. From an analysis of the major structural elements in the social construction of ageing we are able to see the very concept of 'retirement' in a clear historical context. Phillipson demonstrates, with great sensitivity coupled with an ability to draw on telling empirical material, how old age is experienced among the working class in particular and how that experience differs as between women and men. The ideological construction of old age is seen as directly reflected in a range of welfare policies and 
xiv

practices, including the ways in which the elderly are responded to by doctors and social workers. But Phillipson does not fall into the trap of fatalism in the face of the massive forces which are ranged against the elderly poor: on the contrary, this is a combative book which goes on to show that the elderly have a collective role in the struggle for their own liberation from neglect, stigma and oppression. It is a struggle to which the Left should give sustained support.

University of Warwick

December 1981

PETER LEONARD 